\title{
Seismic impedance inversion and attribute analysis for reservoir characterization in an offshore depobelt, Niger Delta, Nigeria
}

\author{
K. F. Oyedele ${ }^{1} \cdot$ O. B. Olatinsu² ${ }^{2}$ A. A. Ige-Adeyeye ${ }^{3} \cdot$ O. A. Obasoro ${ }^{1}$
}

Received: 10 March 2020 / Accepted: 22 September 2020 / Published online: 1 October 2020

(c) Springer Nature Switzerland AG 2020

\begin{abstract}
The task of minimizing pitfall in quantitative reservoir assessment and evaluation is an integral aspect of any promising petroleum exploration and evaluation project. The Niger Delta oil province in Nigeria is chiefly composed of several pay zones with many stratigraphic intervals of sand and shale formations in varying proportion. Whereas conventional seismic interpretation technique poses certain degree of uncertainty in reservoir characterization, seismic inversion constraint by log data brings significant improvement in interpretation that reduces uncertainty in the delineation of reservoir characteristics, volume and distribution. In this present study, post-stack seismic inversion and seismic attributes analysis were used to evaluate the potentials and prospects of mapped reservoirs in a field, offshore depobelt, Niger Delta. The implementation of the tasks consists of mapping of structural framework, horizon picking, log editing and correlation, wavelet extraction, building of low-frequency model, acoustic impedance inversion and crossplot analysis of reservoir properties and attributes. A hybrid approach (formulated using Greenberg-Castagna equation) specific for the Niger Delta depobelts was used to estimate and generate shear wave velocity for the wells. Results obtained from inversion depict an acoustic impedance values in the range $150-280 \mathrm{ft} / \mathrm{s} \mathrm{g} / \mathrm{cc}$ and $V_{\mathrm{p}} / V_{\mathrm{S}}$ of $1.25-2.50$ at a depth range of $9250-9280 \mathrm{ft}$ within the hydrocarbon-bearing sands in the two wells. Region of low acoustic impedance (representing high reservoir porosity) coupled with a corresponding low $V_{\mathrm{P}} / V_{\mathrm{S}}$ ratio (indicating hydrocarbon accumulation) is presumed to have high prospects for exploration and well development. Altogether the degree of correlation between the inverted and actual impedance was found to be about $90 \%$ across the wells. It is evident that the acoustic impedance slice at $3000 \mathrm{~ms}$ depicts low acoustic impedance sand within 18,500-20,000 ft/s g/cc at the northeastern and southeastern regions of the field. High reflection amplitudes (bright spots) signifying hydrocarbon accumulation are also revealed on seismic attribute maps with surrounding shale diaper as the source rock. This study has revealed the prospect (i.e., existence of active petroleum system of probable economic value) of the delineated field in the Niger Delta depobelt.
\end{abstract}

Keywords Seismic inversion $\cdot$ Depobelt $\cdot$ Reservoir $\cdot$ Attributes $\cdot$ Exploration $\cdot$ Petrophysics

\section{Introduction}

Inherent risks and uncertainties associated with hydrocarbon exploration and exploitation have necessitated the need for improved seismic interpretation, lithology and fluid discrimination [1]. Newer and cost-effective technologies and innovations are needed to get over these expected exploration challenges [2]. Seismic inversion technique has been used to improve reservoir characterization, since its inception in the early $1980 \mathrm{~s}$ [3]. Consequently, it has now become a vital tool in the hands of geophysicists involved in reservoir planning and development [4-10]. Seismic inversion is based on seismic derived rock physical properties which are used

O. B. Olatinsu, oolatinsu@unilag.edu.ng| ${ }^{1}$ Department of Geosciences, University of Lagos, Akoka, Lagos, Nigeria. ${ }^{2}$ Department of Physics, University of Lagos, Akoka, Lagos, Nigeria. ${ }^{3}$ Department of Physical Sciences, Lagos State Polytechnic, Ikorodu, Lagos, Nigeria. 
in evaluating reservoir properties and conditions. This involves extracting elastic rock properties from seismic data based on amplitude, travel-time and phase information contained in a seismogram [11-13]. These procedures have made it possible to validate the relationship between elastic and petrophysical properties of reservoir rocks. Most seismic inversion techniques are sensitive to different properties of reservoirs. While these techniques have their respective unique advantages and disadvantages, the applicability of these techniques depends chiefly on the provided geological data, prestack and post-stack seismic data [14]. The incorporation of these techniques and their responses to various petrophysical and elastic properties from well logs, computed logs and inverted logs have translated into improved reservoir characterization [11,15-20]. Petrophysical data are point data which give the real information within the well bore, while seismic data are a lateral sampling of the subsurface with poor resolution when compared with petrophysical data. Some pertinent information (e.g., porosity, permeability, heterogeneity, net pay thickness, etc.) necessary to evaluate a reservoir in terms of its ability to accumulate and deliver hydrocarbon is basically the products of reservoir characterization [16]. In addition, rock physics concepts and modeling have played vital roles in linking elastic rock properties (elastic wave velocity and impedance) to porosity, mineralogy (shale content), saturation, and pore fluid properties as well as predicting the effect of fluid substitution on porous and fractured reservoir and monitoring changes in reservoir elastic properties during production [21-25]. This has found numerous applications in establishing the link between seismic impedance and velocity inversion with physical reservoir properties. Generally, these empirical relations play important roles in data integration, especially in data sets that are difficult to acquire in situ. In well logging, a typical scenario is when shear wave velocity data are unavailable, and in which case different methods have to be developed with the objective of filling the data gaps [26]. Hence in situations where data quality is grossly inadequate, post-stack acoustic impedance inversion is able to effectively discriminate between hydrocarbon bearing zones and non-bearing zone. Also, analyses and interpretation based entirely on conventional seismic technique is very uncertain in predicting rock properties. Therefore, this study integrates structural interpretation, seismic acoustic impedance inversion (model based post-stack) as well as seismic attribute analysis to reduce the uncertainty in the prediction and delineation of the characteristics, disposition and distribution of hydrocarbon bearing reservoir in a field, offshore depobelt, Niger Delta.

\section{The Niger Delta geological setting}

The Niger Delta Basin covers a region of about $70,000 \mathrm{~km}^{2}$ in the Gulf of Guinea, West Africa (Fig. 1). It was formed in the Early Tertiary, with the accumulation of sediments during the Mesozoic rifting of African and South American continents. It is divisible into continental, marginal marine and marine facies [27]. The Tertiary deltaic fill of the Niger Delta is represented by a strongly diachronous (Eocene-Recent) structure which is divided into three lithofacies units namely: Akata Formation, Agbada Formation and Benin Formation, respectively [28-30]. The Agbada Formation which is a paralic sequence of shale and sand interbeds is the primary reservoir of oil/gas in the Niger Delta clastic wedge. The matured Eocene and Miocene shale of the Akata and Agbada Formation constitute the major source rock [29, 31-33]. Synrift marine clastics and carbonates deposition which occurred during a succession of transgressive and regressive phases between the Cretaceous to Early Tertiary constitute the oldest dated sediments of the Albian age [34]. The differential loading of undercompacted shale at the bottom of the Tertiary Delta by the relatively heavy sandy deposits initiated the formation of growth fault in the basin, and this can result in growth fault plane or a roll-over anticline if sufficient movement takes place along the line of deposition [35]. Rapid sedimentation and gravitational instability during the accumulation of the Agbada deposits and continental Benin sands over the mobile under-compacted Akata prodelta shale, is the main cause of the growth fault. The generic and distinctive properties manifested by the oil bearing reservoir of the Niger delta are a function of the sand/shale ratio and sealing potential of the faults [36-38]. Two possible migration routes have been established in the Niger Delta. These are: (1) migration along the structure building faults which terminate in the Akata Formation and (2) migration from the seaward facies up-dip into the rollover structures [29]. Lateral flowage and extrusion of the Akata prodelta shale during growth faulting also account for the diapiric structure on the continental slope of the Niger delta in front of the advancing depocentre of paralic sediment $[36,38]$. The series of punctuations in the progradation of the deltaic system defines a depobelt. Depobelts which strike Northwest-Southeast, sub-parallel to the shoreline, successively become younger basin ward, ranging in age from Eocene in the north to Pliocene offshore to the present day shoreline. The structural style deep water fold and thrust belts of the Niger Delta are system with a single basal detachment level, that is typically near the top of the Akata Formation and multiple basal detachment 
Fig. 1 Regional geology of the Deepwater Niger Delta showing the "Apok" field. Adapted from [41]

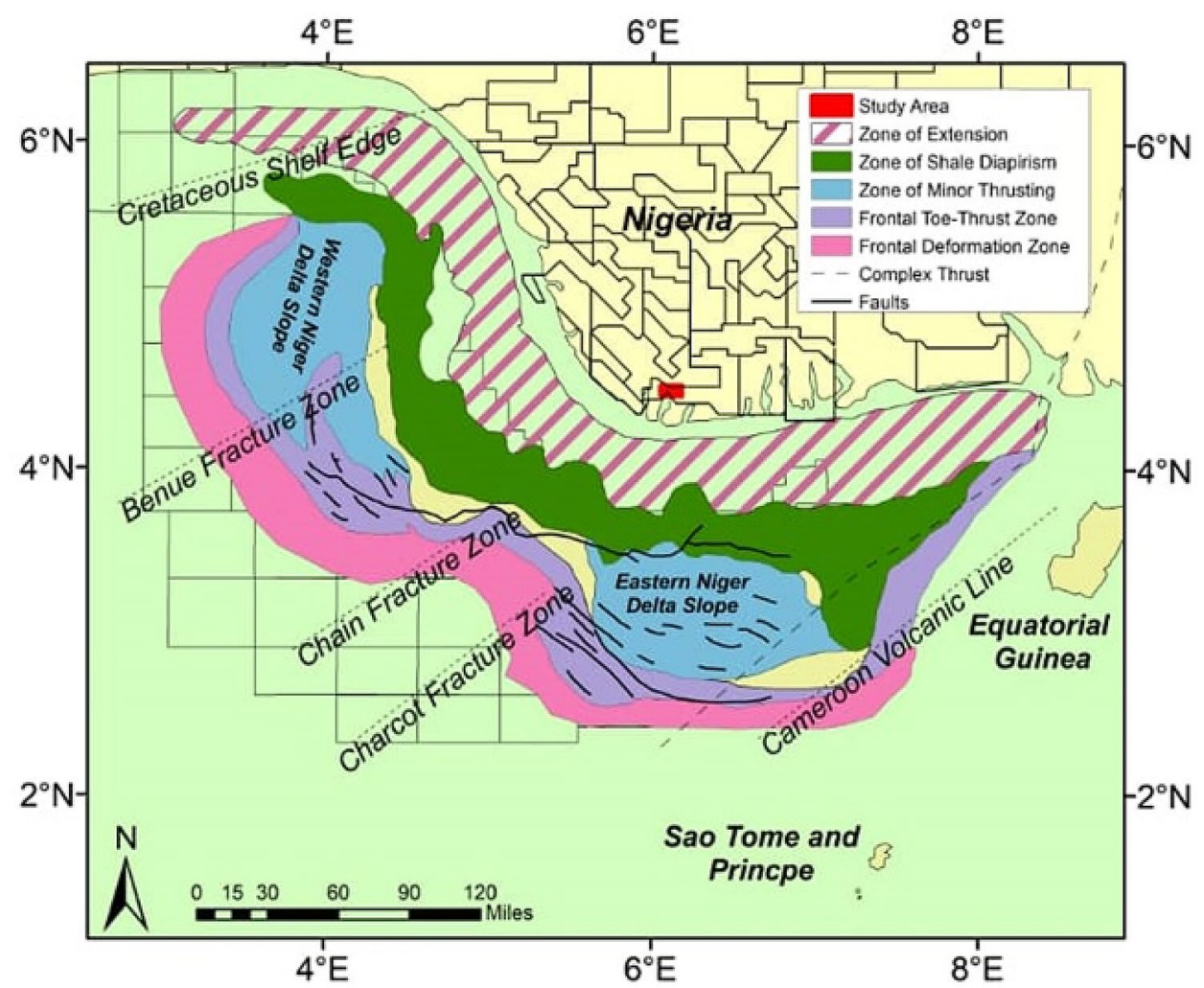

levels, which causes massive structural thickening of the Akata Formation and refolding of shallow thrust sheets $[39,40]$.

\section{Methodology}

An integrated data set was used in this study for the structural mapping, seismic inversion and reservoir attributes analysis. These include: 3D post-stack seismic data, suites of well logs (gamma ray log, resistivity log, neutron log and density log) for wells Freeman-001, 003, 004 and 005 (Fig. 2). However, only two wells (Freeman-001 and 005) which are extensive and well-connected with the major reservoirs are considered for interpretation.

\section{Well to seismic tie}

Delineation of the geometry and structural framework of reservoirs was accomplished by tracking seismic reflection events on the seismic volume. Well data were converted from depth domain to time domain to correlate the well and seismic data for horizon picking. Figure 3 shows the seismic section with crossline and inline running east-west and north-south, respectively. Two horizons ( 1 and 2) were identified on the seismic volume (Fig. 3) and incorporated into the workflow for seismic inversion. The zones of interest (sand bearing hydrocarbon) are located at reflection time $2852.5-28,625 \mathrm{~ms}$ (9240-9290 ft of TVD) and 3370-3390 ms (9700-9775 ft of TVD) for Freeman-001 and 005 , respectively. Well to seismic tie was done using Hampson-Russel STRATA program [42] and Petrel software.

\section{Wavelet extraction, model-based inversion and rock physics}

In post-stack seismic inversion techniques, stacked (zerooffset) seismic data are used to produce images of acoustic impedance in depth or time. Acoustic impedance as one of rock physics elastic parameters is influenced by lithology, porosity, fluid content, etc. Wavelet extraction was conducted within the reflection time window to extract a zero phase wavelet from the seismic section and well logs. This process involves building an initial model with a starting low frequency model followed by modification through successive iteration to optimally fit the seismic data (Fig. 4), thereby minimizing error in the model-based inversion $[43,44]$. This model-based inversion technique converts seismic data to a pseudo-acoustic impedance log at every trace. Figure 5 shows the wavelet in frequency and time domain, while Fig. 6 shows the corrected P-wave and time-depth shift for the inversion. As an input into 
Fig. 2 Base map showing the available wells (Freeman-001, 003,004 and 005 in the study area
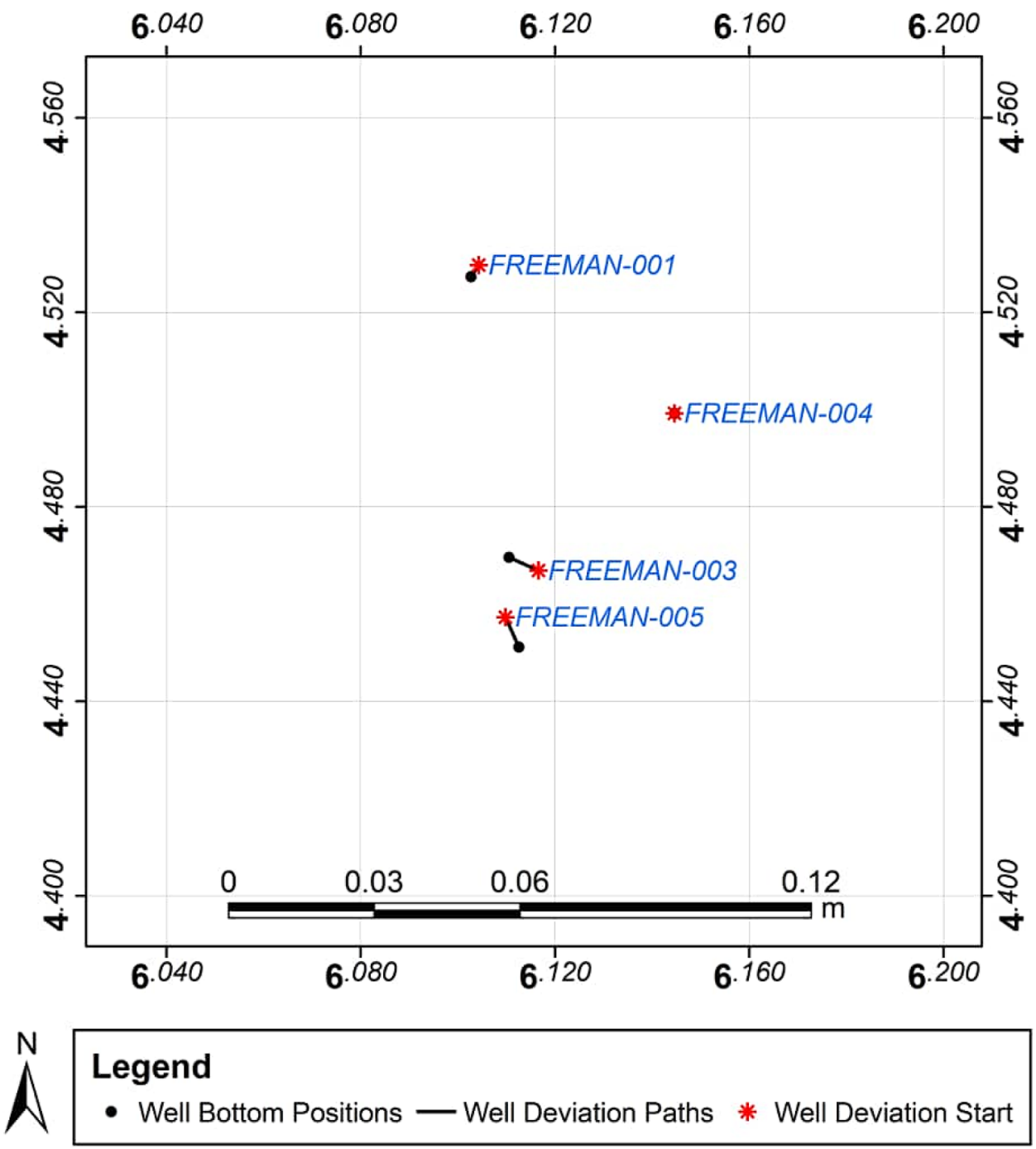

Fig. 3 Horizon mapping on seismic section showing the location of freeman-001 and 005 penetrating the main reservoir and the two horizons identified for interpretation

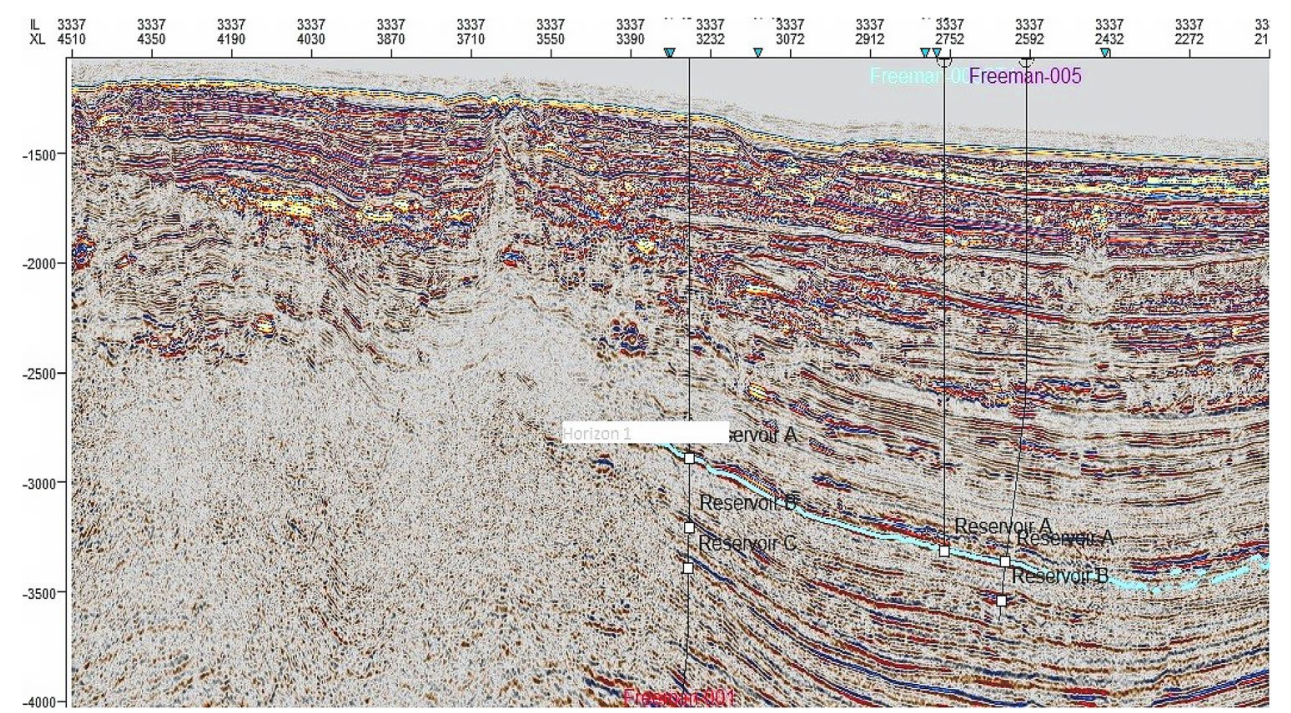


Fig. 4 Inversion and interpretation workflow

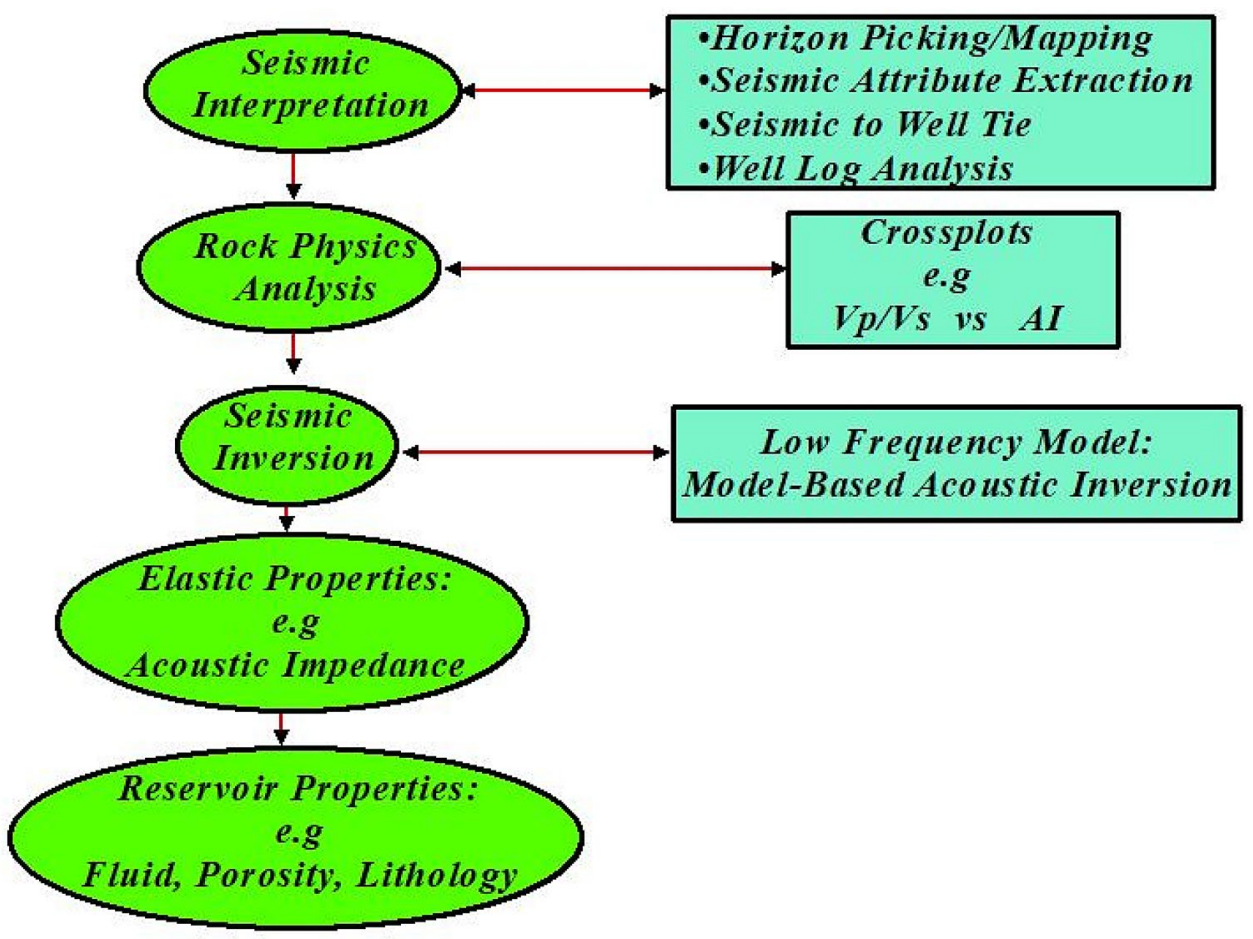

the inversion, an initial acoustic impedance model $\left(I_{P}\right)$ was generated from density $(\rho)$ and P-wave velocity $\left(V_{P}\right)$ log using the equation: $I_{\mathrm{p}}=\rho * V_{\mathrm{p}}$. The predicted and original acoustic impedance curves were compared via inversion analysis. The shear wave velocity was extracted using modified form of Greenberg-Castagna equation [45] to generate shear wave velocity for crossplot analysis. Velocity or impedance measurements in Lamé parameter, incompressibility $(\lambda)$ and rigidity $(\mu)$ provide an alternative interpretation methodology [46]. Besides, two other attributes, LambdaRho $(\lambda \rho)$ and MuRho $(\mu \rho)$ or Lamé impedances, were formulated and introduced [47], and referred to the method as Lambda-Mu-Rho or LMR. Since there is a link between $V_{p}$ and $V_{S}$ using the modified Greenberg-Castagna equation, it is possible to calculate $\lambda \rho$ and $\mu \rho$ from $\lambda \rho=l_{\mathrm{p}}^{2}-2 l_{S}^{2}$ and $\mu \rho=l_{S}^{2}$ respectively, once compressional and shear impedance volumes are available where $I_{S}$ is the shear impedance. Lastly, rock physics model (RPM)-based interpretation templates for LMR would permit interpretation and comparison of log or seismic derived elastic properties [47].

\section{Seismic attributes analysis}

Seismic amplitude was used for seismic attribute analysis in identifying hydrocarbon reservoirs and sediment depositional direction from its source. Seismic variance attribute extracted was used in delineating structures that could serve as hydrocarbon accumulation. Rock physics properties analysis was carried out across Freeman-001 and 005 wells that penetrated the main reservoir. A crossplot of $V_{\mathrm{P}} / V_{\mathrm{S}}$ against acoustic impedance (Al) which is a well-known fluid discriminator of hydrocarbon was obtained with the pseudo-shear wave velocities $\left(V_{S}\right)$ calculated from a hybrid approach formulated using Greenberg-Castagna equation [48] specified for the offshore depobelts of Niger Delta region. This shows expected trend $\left(V_{S}=0.919 V_{p}-1.14\right)$ between compressional and shear wave velocities in a typical offshore Niger Delta Basin. Other authors have also established similar linear trend between shear wave and compressional wave velocities for some reservoirs in the northwestern part of the Niger Delta Basin as given in Table 1 [18, 45, 49].

\section{Results and discussion}

Reservoir characterization to evaluate reservoir properties from seismic data using impedance inversion model and interpretation has been carried out on two wells in this study. Figure 7 shows the time structural map with time ranging from $2550-3750 \mathrm{~ms}$ at contour interval of $150 \mathrm{~ms}$ for horizon 1 and $3100-4100 \mathrm{~ms}$ at contour interval of $200 \mathrm{~ms}$ for horizon 2. The corresponding depth map for the two horizons are presented in Fig. 8 with depth ranging from $2150-3350 \mathrm{ft}$ at contour interval of $200 \mathrm{ft}$ for horizon 1 and $2400-4500 \mathrm{ft}$ at contour interval 


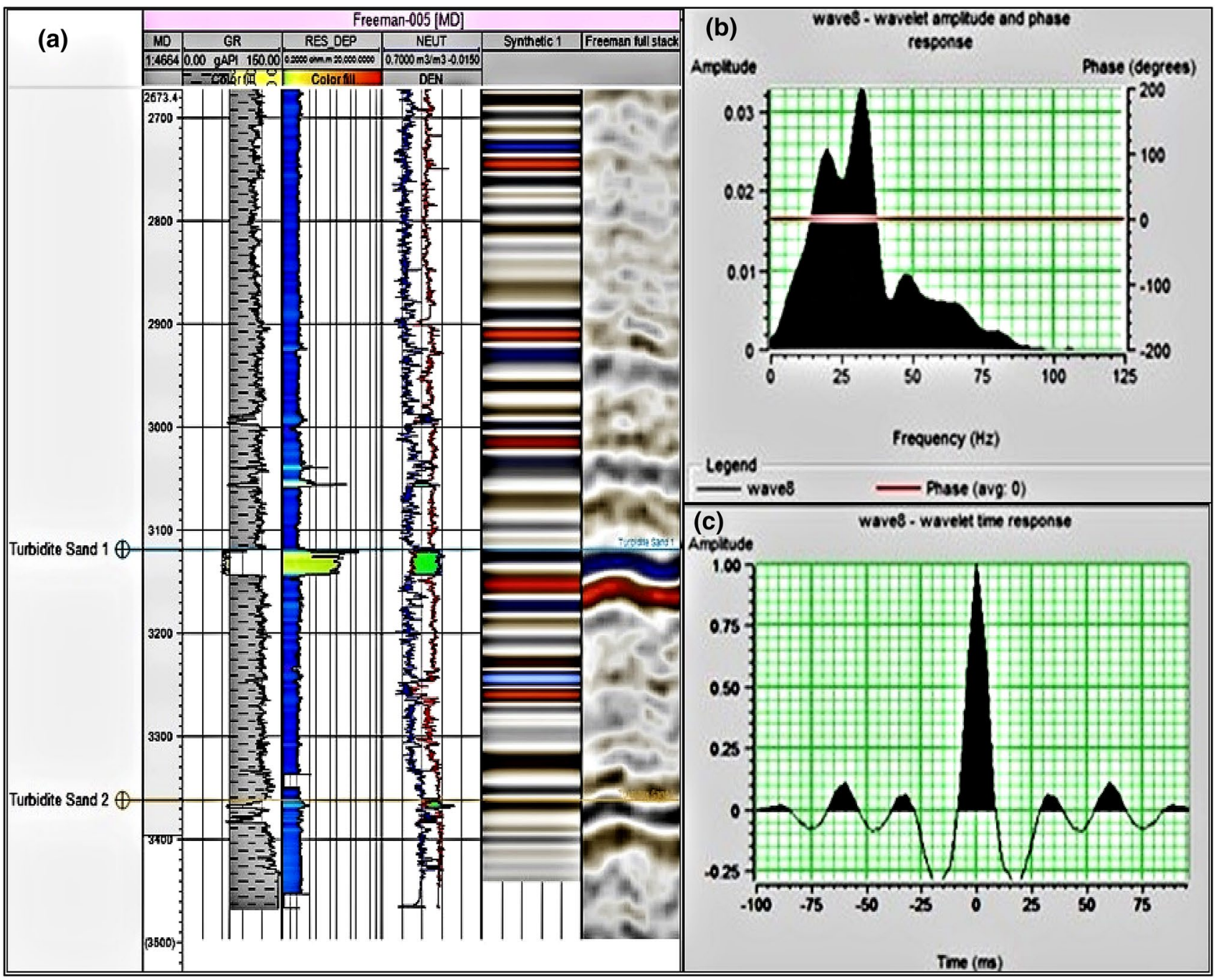

Fig. 5 a Wavelet extracted on Freeman-005 using Petrel; b full wavelet in frequency domain; c full wavelength in time domain

of $300 \mathrm{ft}$ for horizon 2. The circled crosses in Figs. 7, 8 and 9 indicate the locations of the wells. These delineated features show structural high or anticline (host to hydrocarbon deposit) at the northeastern part and structural low at the southwestern part of the map.

Analysis of relevant seismic attributes such as rootmean-square (RMS) amplitude helps as direct hydrocarbon indicators $(\mathrm{DHI})$ in delineating potential hydrocarbon zones to enhance interpretation [50,51]. Figure 9 depicts the RMS seismic attribute extracted for the two horizons. High amplitude is observable on eastern, southeastern as well as southwestern parts for horizon 1 , while for horizon 2, dim spots are observable at the eastern and southwestern parts on the RMS map. This might be attributed to poor resolution due to drop in frequency of the seismic energy. Figure 10 shows the seismic variance attribute map. On northeastern part, a shale diapiric structure is revealed as the main trapping mechanism over the anticlinal structure on the two horizons.

Synthetic seismogram and seismic data correlation for the two wells are shown in Fig. 11a, b. The total correlation 

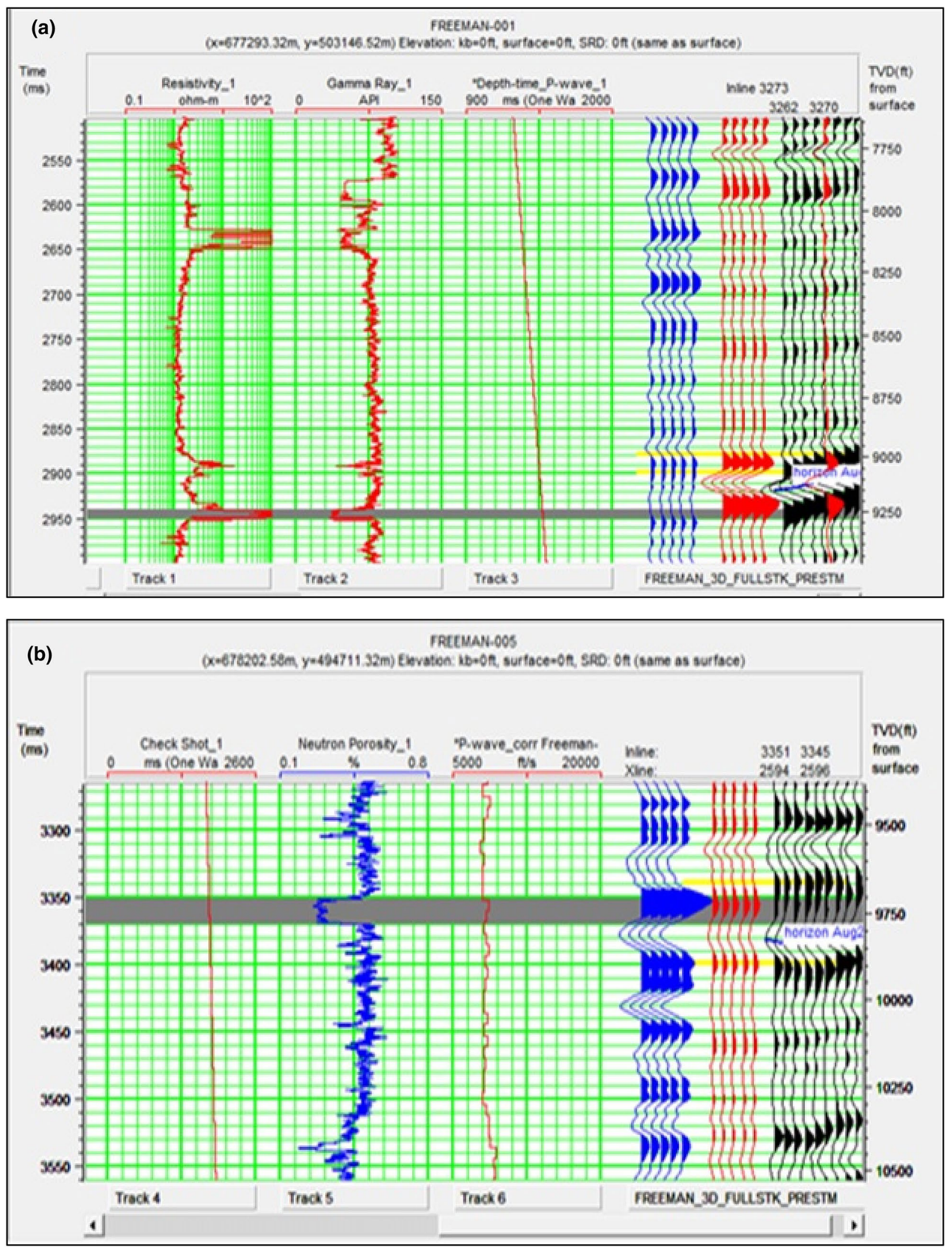

Fig. 6 Corrected P-wave and time-depth shift for inversion: a Freeman-001 and b Freeman-005, respectively 
Table 1 Examples of the Greenberg-Castagna relationships predicted for some oil fields in the Niger Delta Basin

\begin{tabular}{lll}
\hline Linear relation between $V_{S}$ and $V_{P}$ & Formation & Authors \\
\hline$V_{S}=0.80416 V_{P}-0.85588$ & Sand beds/reservoir & Horsfall et al. [49] \\
$V_{S}=0.80430 V_{P}-0.85610$ & Sand beds/reservoir & Oyedele et al. [18] \\
$V_{S}=0.76969 V_{P}-0.86735$ & Shale beds & Horsfall et al. [49] \\
$V_{S}=0.77240 V_{P}-0.86680$ & Shale beds & Oyedele et al. [18] \\
$V_{S}=0.919 V_{P}-1.14$ & Deepwater/Offshore reservoir & Ebere [45] \\
\hline
\end{tabular}

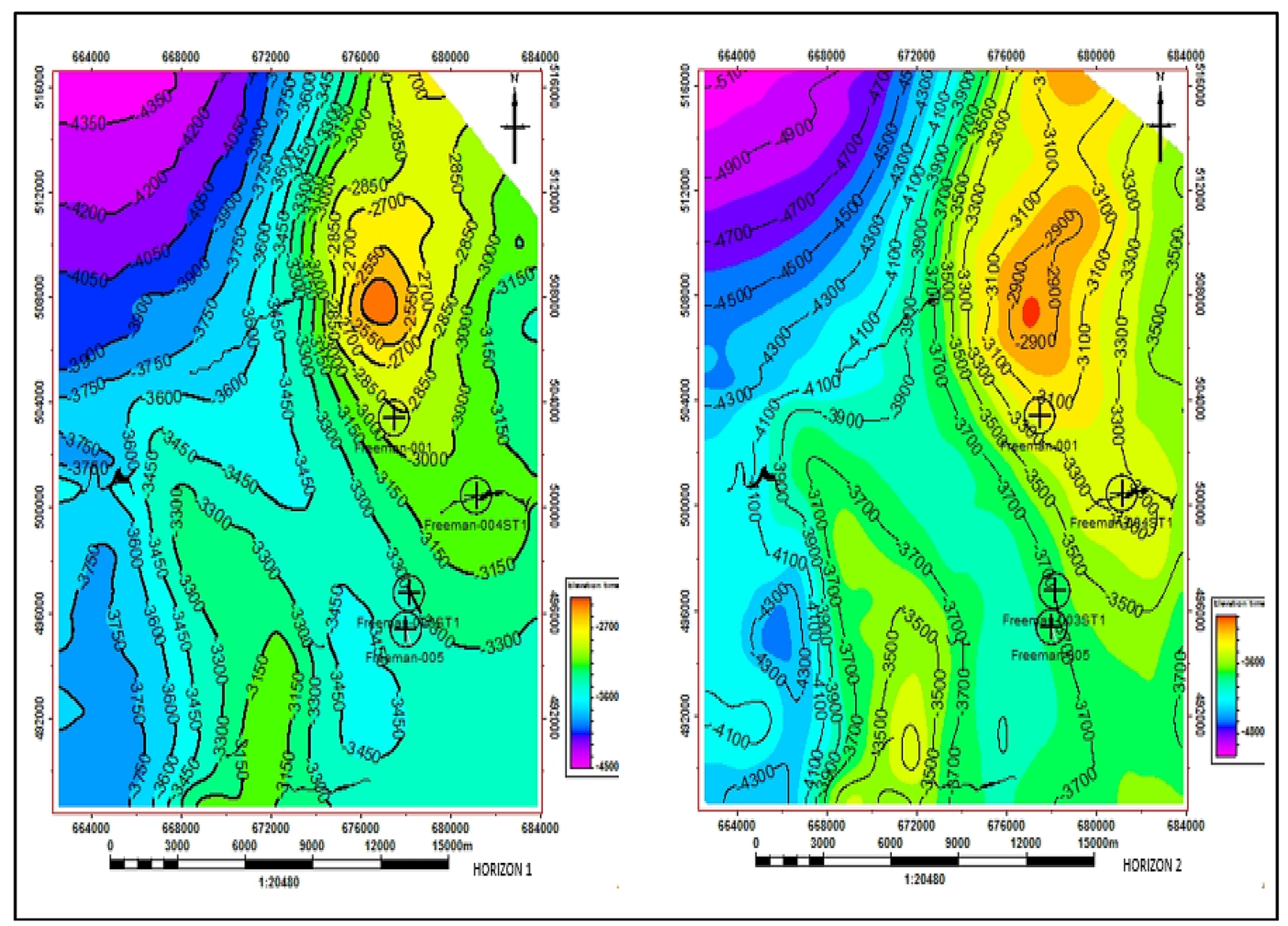

Fig. 7 Time structural map for Horizon 1 and Horizon 2, respectively

between the actual trace and synthetic trace used for inversion is about $90 \%$. Figure $12 \mathrm{a}$, b shows the result from the model-based inversion for Freeman-001 at $2950 \mathrm{~ms}$ and $9250 \mathrm{ft}$ (TVD) and for Freeman-005 at $3350 \mathrm{~ms}$ and $9750 \mathrm{ft}$ (TVD) respectively. Impedance map shows distribution of reservoir properties. Acoustic impedance map is the base for reservoir parameter distribution and dynamic modeling. Figure 13a shows the cross section of acoustic impedance and $V_{\mathrm{P}} / V_{\mathrm{S}}$ ratio, respectively. The crossplot of acoustic impedance (Al) and $V_{\mathrm{P}} / V_{\mathrm{S}}$ using gamma log as legend to classify hydrocarbon zone is presented in Fig. 13b. The blue zone represents the probable sand bearing zone which depicts acoustic impedance values in the range $150-280 \mathrm{ft} / \mathrm{s} . \mathrm{g} / \mathrm{cc}$ and $V_{\mathrm{p}} / V_{\mathrm{S}}$ ratio of $1.25-2.50$ at a 


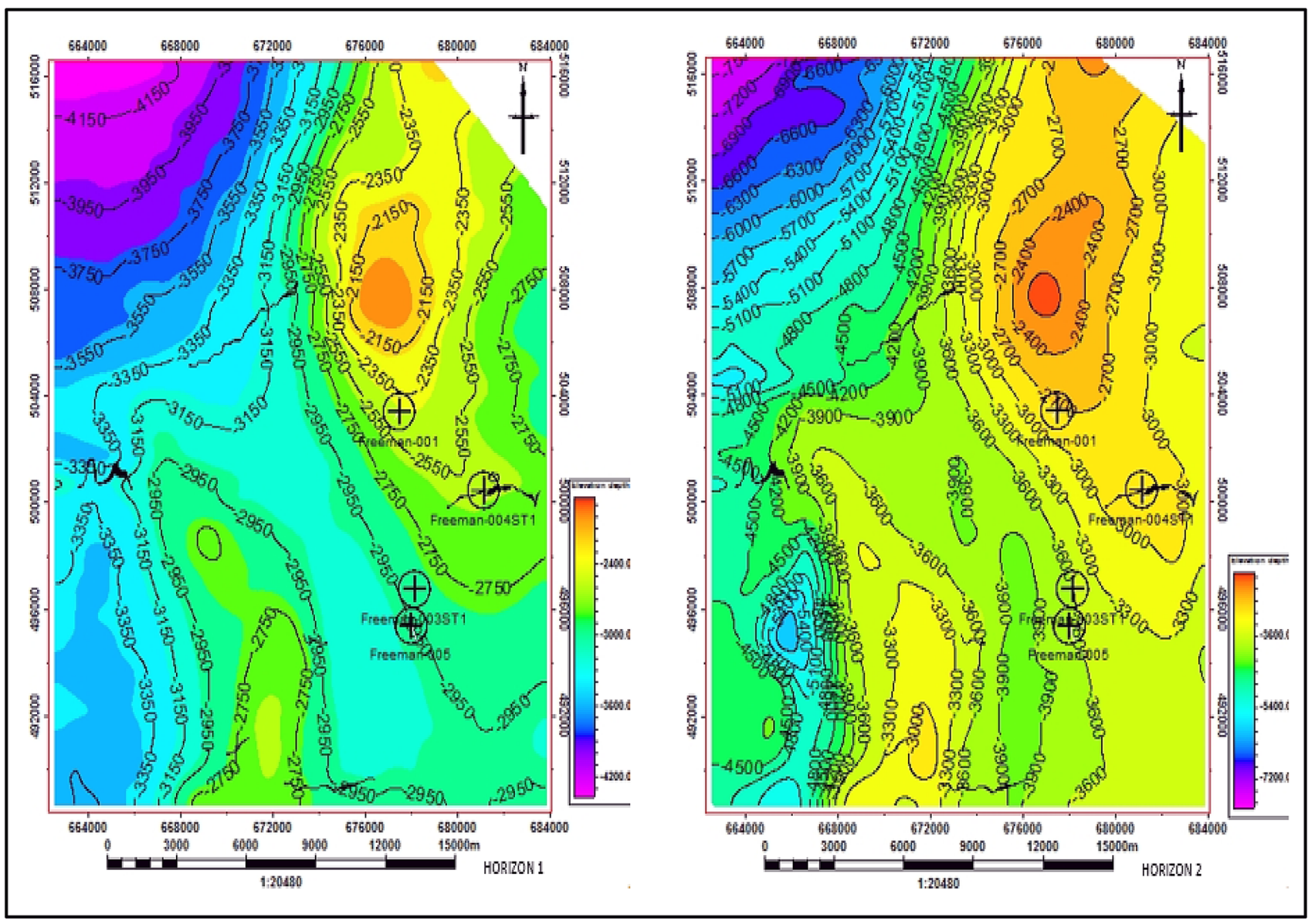

Fig. 8 Depth map for Horizon 1 and Horizon 2, respectively

depth range of 9250-9280 ft within the hydrocarbon-bearing sands. A region of low acoustic impedance (representing high reservoir porosity) coupled with a corresponding low $V_{\mathrm{p}} / V_{\mathrm{S}}$ ratio (indicating hydrocarbon accumulation) is presumed to have high prospects for exploration and well development. In hydrocarbon-saturated reservoir, acoustic impedance (Al) is usually lower for the reservoir sand medium than the surrounding shale formation. At a depth range of 9700-9750 ft and 9200-9250 ft, a lower $\mathrm{Al}$ is observed compared to the surrounding shale formation on the reservoir for Freeman-001 and Freeman-005, respectively. Lower values of $\mathrm{Al}$ (lower density, lower velocity) indicate better reservoir properties as porosity. Figure 14 shows the initial model built to enhance the inversion of whole seismic volume and the full inverted volume of the model-based acoustic impedance inversion. The initial model is the prior low-frequency model generated from low-pass-filtered acoustic impedance logs from the wells and extrapolated along all the events in the seismic data. This is the absolute level of acoustic impedance for the seismic data. Figure 15 shows the correlated well inversion log of Freeman-001 and 005, which give a high correlation of about 0.90 between inverted acoustic impedance and initial well data. The low error in correlation increases the confidence of interpretation. Figure $16 \mathrm{a}$ shows the time slice of acoustic impedance at $3000 \mathrm{~ms}$ within the reservoir. The two wells fall within the regions of low impedance. This resistive, low impedance region is indicative of fluid-saturated medium. The Lambda-Mu-Rho (LMR) inverted volumes (Fig. 16b), in conjunction with LMR 


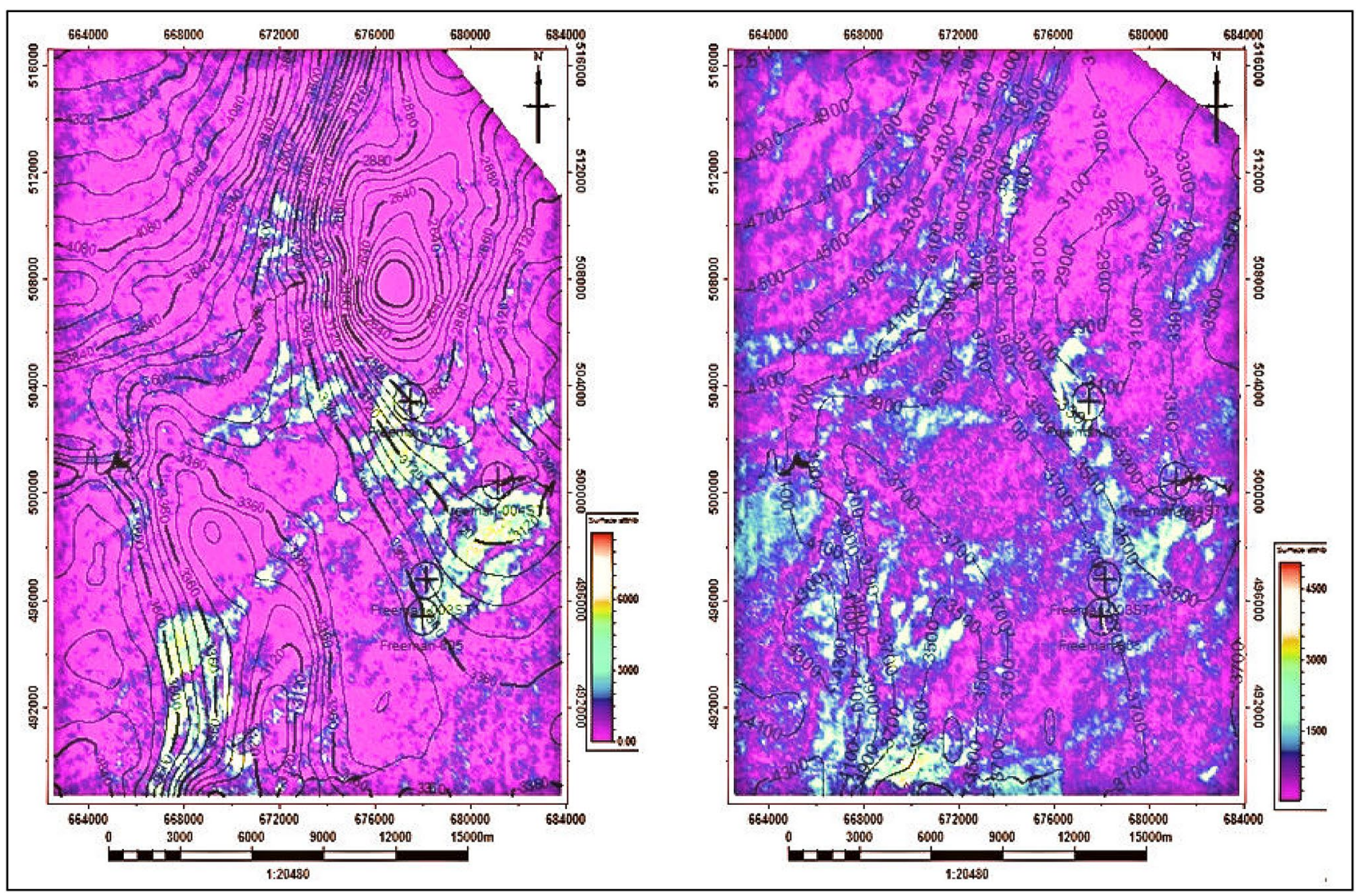

Fig. 9 RMS seismic attribute extracted for Horizon 1 and Horizon 2, respectively

Fig. 10 Seismic variance attributes for: a Horizon 1 b Horizon 2 , respectively

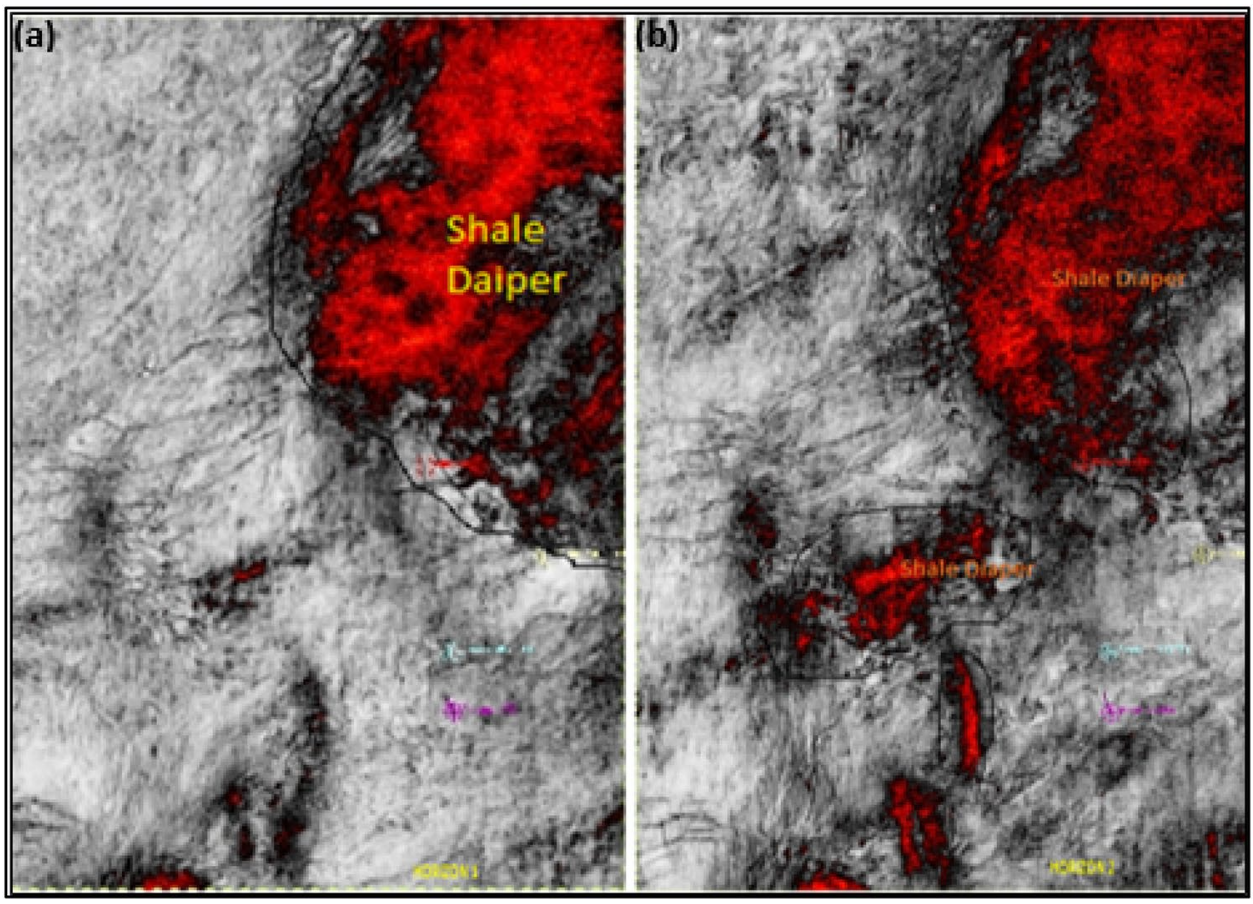



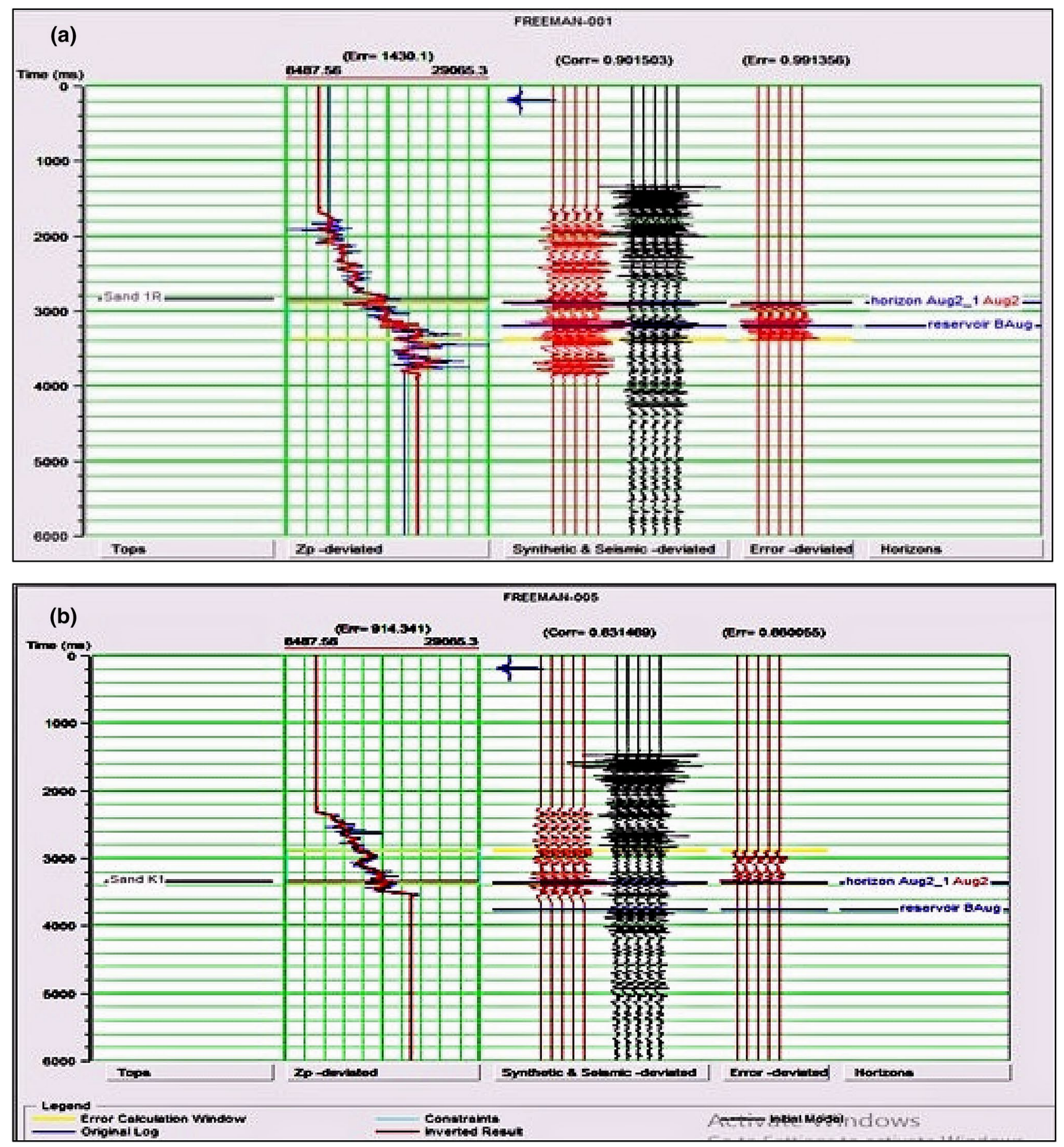

Fig. 11 Synthetic seismogram and seismic data correlation with the errors. The red and black traces are the synthetic and seismic trace, respectively. The red lines on the right-hand side of the seismic trace indicate the error between the synthetic used for the inversion and real seismic data 

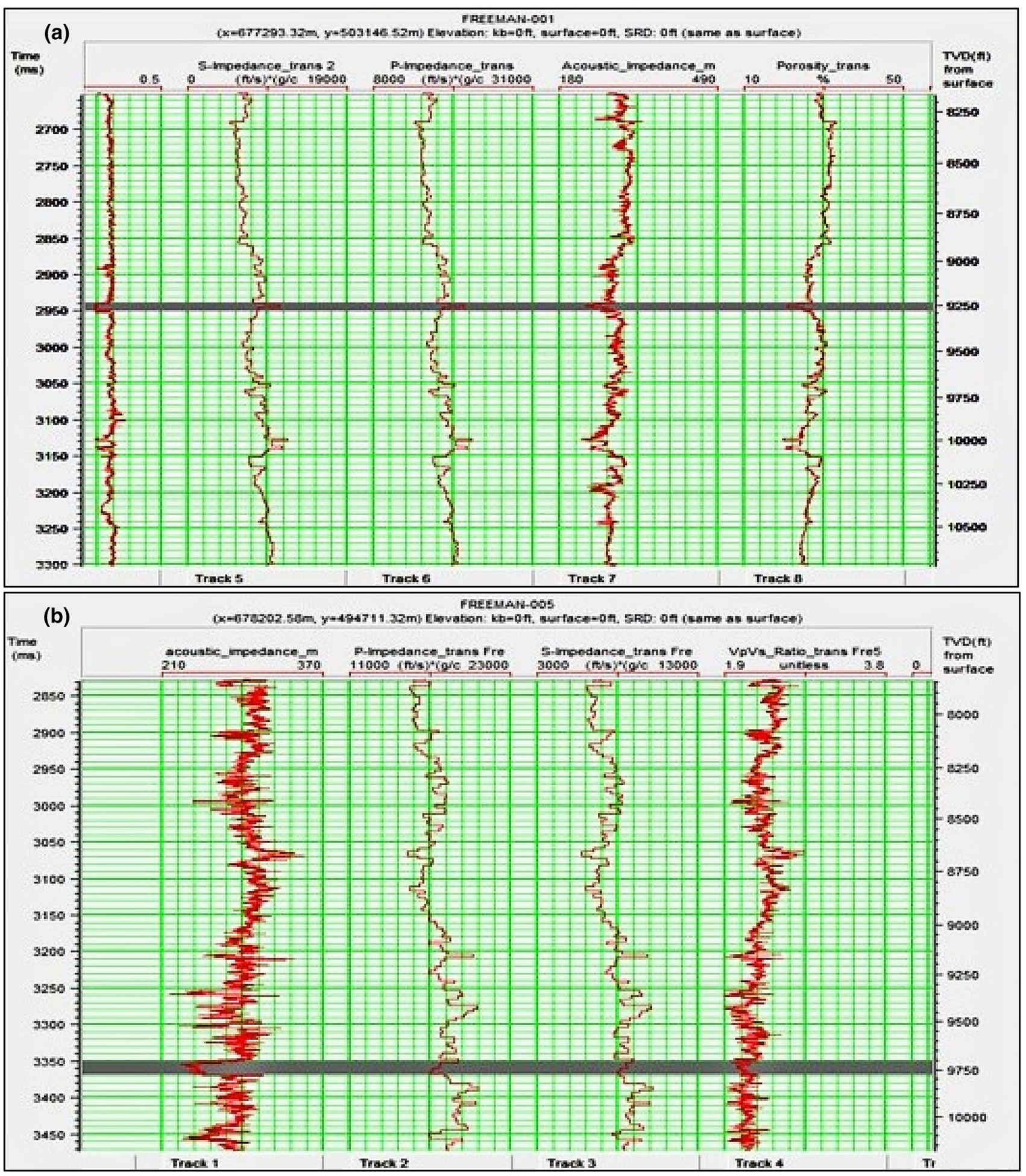

Fig. 12 Generated logs showing P-impedance, computed S-impedance, $V_{p} / V_{s}$ and porosity for the two wells: a Freeman-001; $\mathbf{b}$ Freeman-005 respectively 

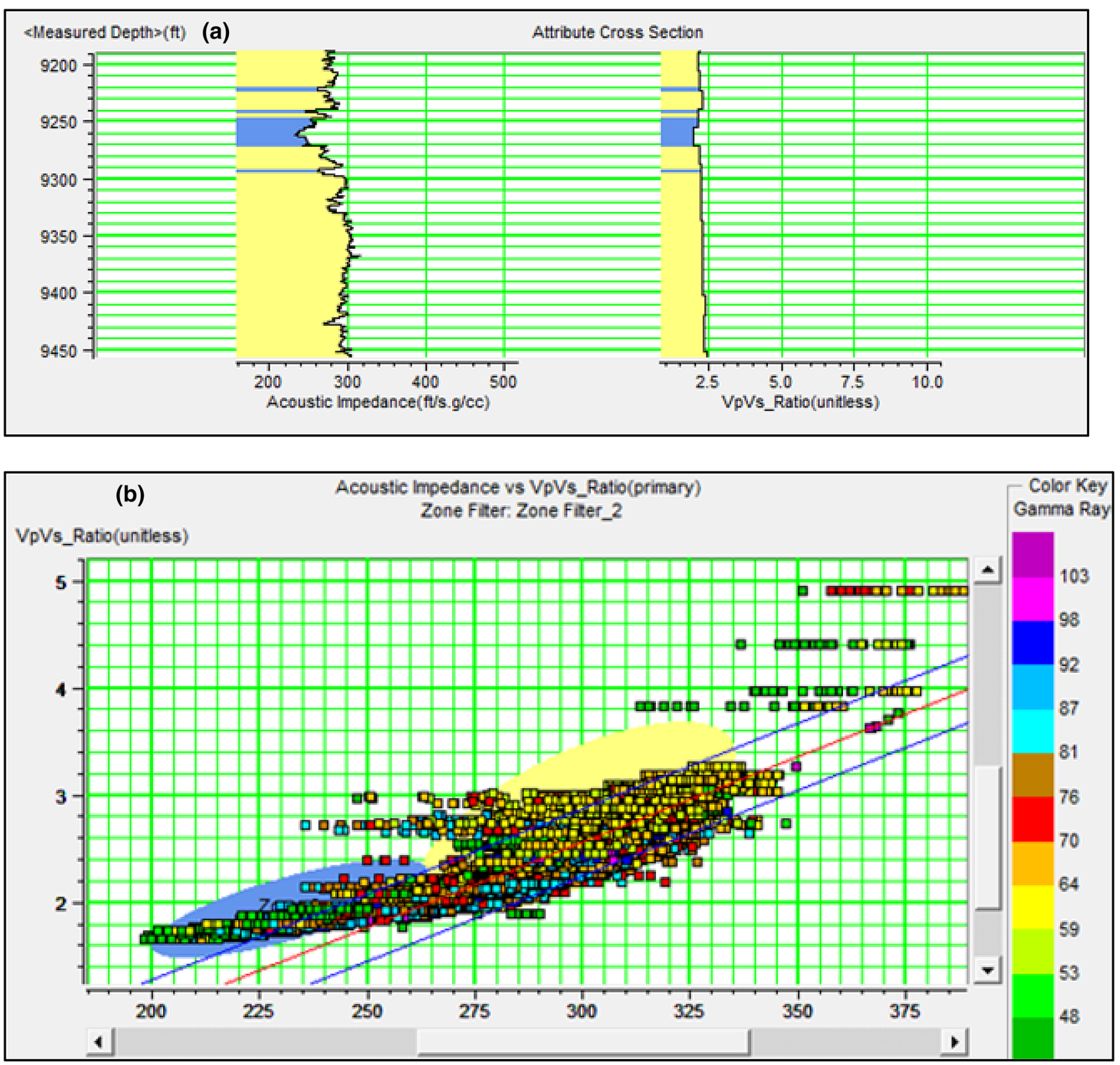

Fig. 13 a Cross section relationship of acoustic impedance (Al) and $V_{\mathrm{p}} / V_{\mathrm{s}}$ ratio within the productive zone; $\mathbf{b}$ crossplot of acoustic impedance and $V_{\mathrm{p}} / V_{\mathrm{s}}$ ratio using gamma log legend to classify $\mathrm{HC}$ zone (blue zone represents the probable bearing sand) 

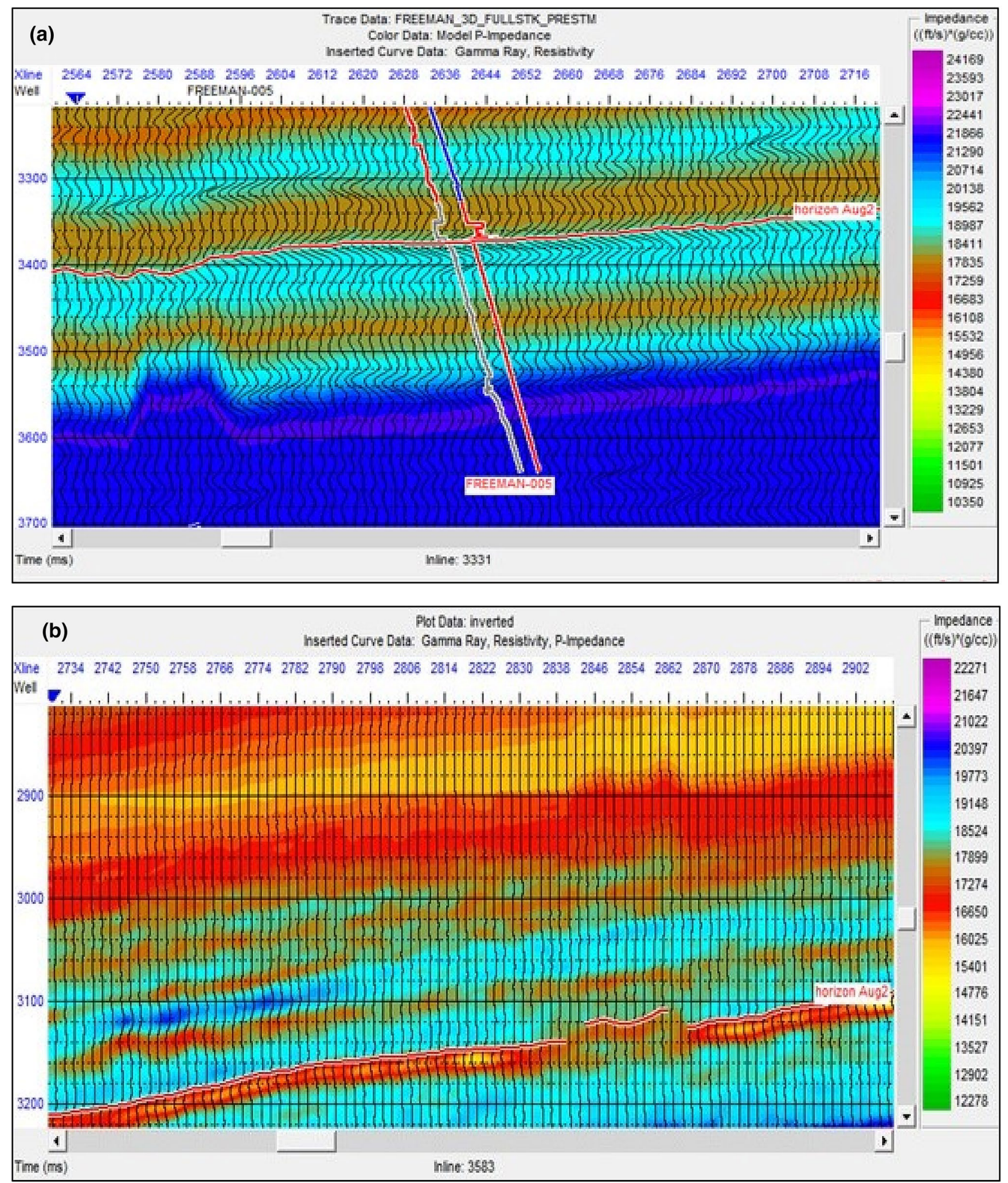

Fig. 14 a Initial model built for inversion; $\mathbf{b}$ Full inverted volume of model-based acoustic inversion 


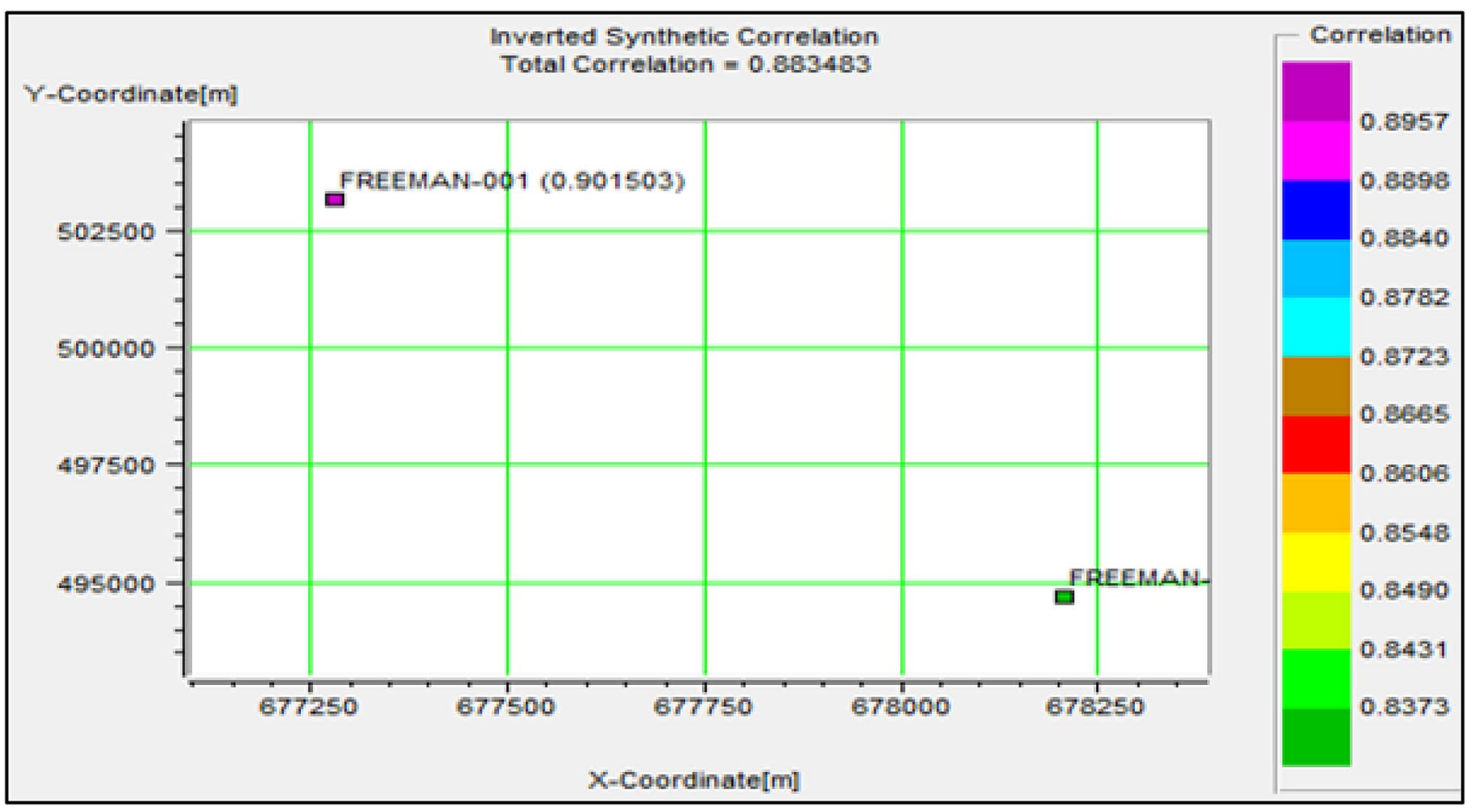

Fig. 15 Correlation of the two wells and relative error

histogram (Fig. 17b), indicate that Al clearly discriminates between hydrocarbon zones and the surrounding zone. The Al histogram shown in Fig. 17a also reveals a lower Al values for hydrocarbon zone compared with the surrounding shale.

\section{Conclusion}

Integrated 3D seismic interpretation, post-stack inversion and attribute analysis have been carried out for inclusive reservoir characterization in a field in offshore depobelt, Niger Delta, Nigeria. Results show robust integration approach as an important tool in reservoir characterization and its necessity in reducing the risks involved in drilling. Horizon mapping, crossplot analysis and inverted volumes facilitated the discrimination of hydrocarbon sands from shale sands. The inversion output also conforms with structure which makes for a very robust reservoir characterization. Amplitude anomalies observed on horizons showed the presence of hydrocarbon in the delineated reservoirs. This was further established by the inversion results which improves the reservoir characterization. The inversion results (seismic variance attributes) also helped map lithologies (shale diaper from sand) and aided interpretation of the geological structure in the oil field depobelt Niger Delta. The attribute volume of acoustic impedance (Al) has assisted the delineation of hydrocarbon-saturated reservoirs and has also served as tools for mitigating risks connected with exploration works. The use of post-stack inversion results revealed better reservoir architecture and characterization in the field investigated. Consequently, that conventional 3D seismic interpretation should not be used as a stand-alone method for seismic interpretation due to the uncertainty in predicting rock physics analysis of oil reservoir is affirmed. The result obtained could be used to carry a dynamic modeling and monitoring. Finally, applying inversion algorithm on data from a specific geologic condition (i.e., Niger Delta oil province) is a major contribution from this study. 

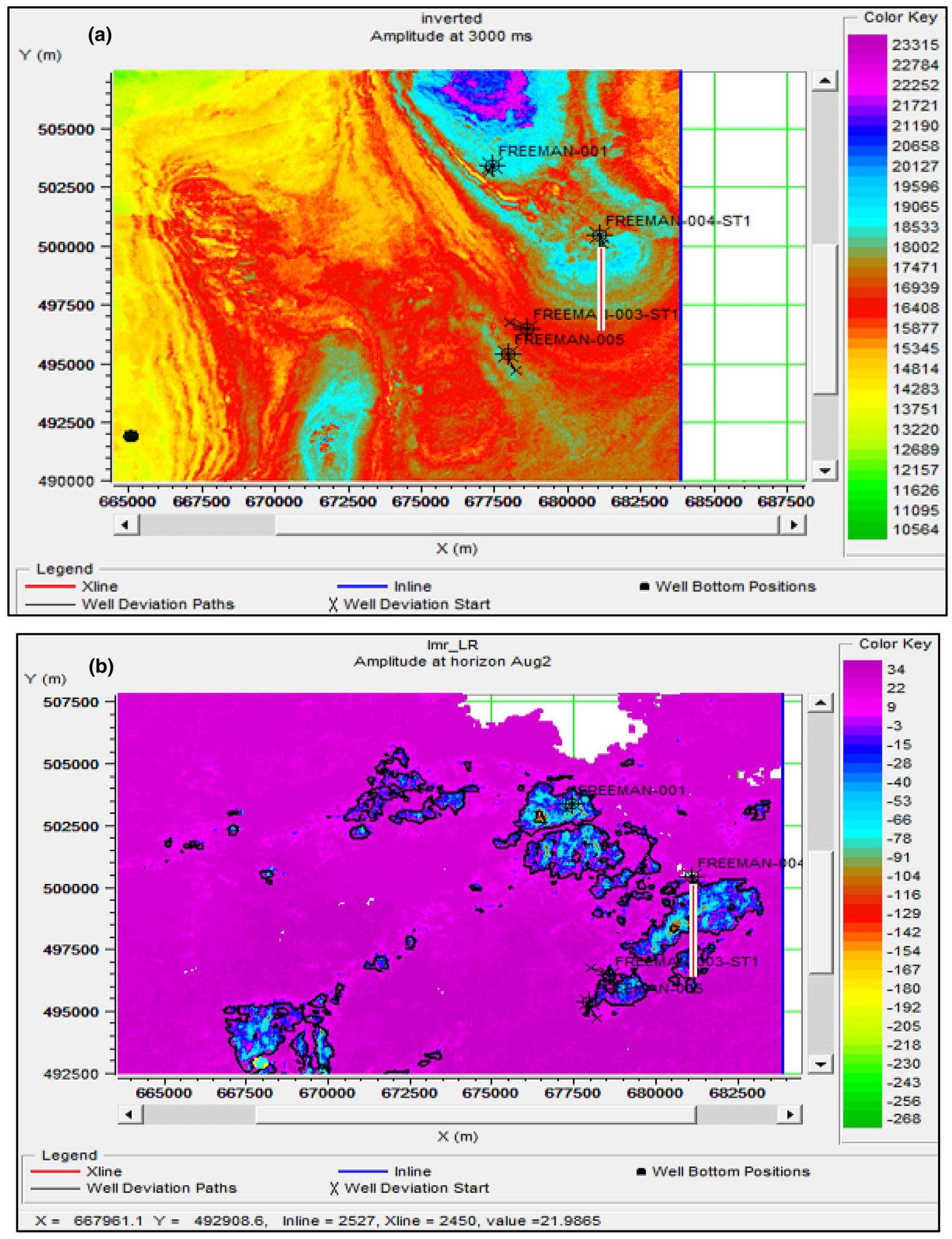

Fig. 16 a Time slice (3000 ms) of the distribution of acoustic impedance; $\mathbf{b} \operatorname{LMR}(\lambda \rho)$ inverted volume slice at $-3000 \mathrm{~ms}$ 

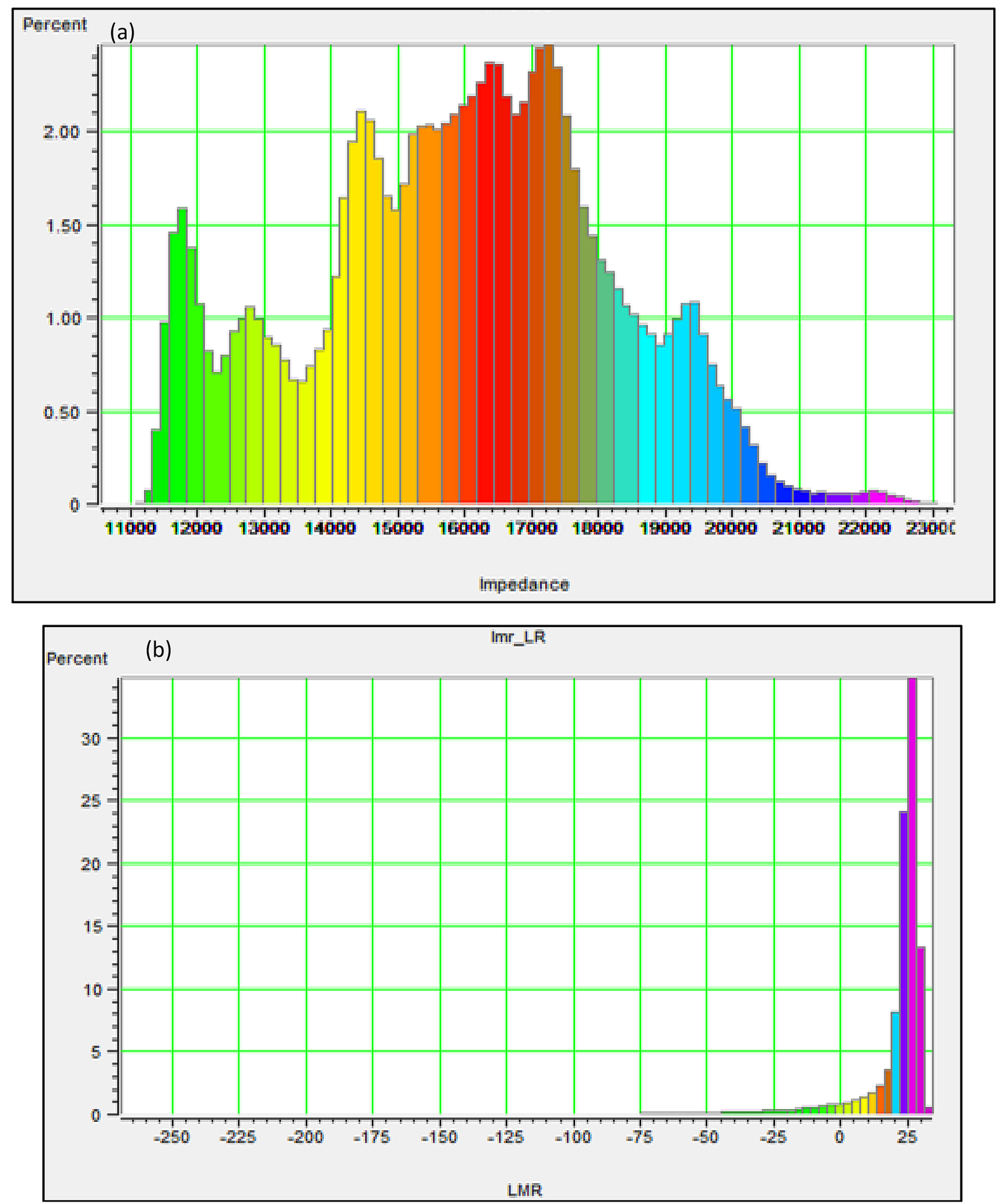

Fig. 17 a Acoustic impedance histogram model; b LMR histogram model 
Acknowledgements The authors acknowledge the support of the Department of Petroleum Resources (DPR) for providing the linkage to the Petroleum Company that supplied the data used in this study. We are grateful to the unanimous company for releasing the data. Many thanks to the Department of Geosciences, University of Lagos, Akoka, Lagos, Nigeria, for the workstation used for the data analysis and interpretation. The editor and the two unanimous reviewers are highly appreciated for their painstaking efforts and constructive comments in the review process that has greatly improved the quality of this work.

\section{Compliance with ethical standards}

Conflict of interest The authors declare no conflict of interest.

\section{References}

1. Ødegaard E, Avseth P (2004) Well log and seismic data analysis using rock physics templates. First Break 22(10):37-43. https:// doi.org/10.3997/1365-2397.2004017

2. Yuan S, Wang Q (2018) New progress and prospect of oilfields development technologies in China Petrol. Explor Dev 45(4):698-711

3. Pendrel J (2001) Seismic inversion - the best tool for reservoir characterization. CSEG Recorder 26(1):16-23

4. Avseth P, Mukerji T, Mavko G (2005) Quantitative seismic interpretation applying rock physics tools to reduce interpretation risks. Cambridge University Press, Cambridge

5. Jackiewicz J (2009) Seismic inversion methods. AIP Conf Proc 1170(1):574-576

6. Leite EP, Vidal AC (2011) 3D porosity prediction from seismic inversion and neural networks. Comput Geosci 37(8):11741180. https://doi.org/10.1016/j.cageo.2010.08.001

7. Kemper M, Gunning J (2014) Joint impedance and facies inversion-seismic inversion redefined. First Break 32(9):89-95

8. Maurya SP, Sarkar P (2016) Comparison of post-stack seismic inversion methods: a case study from Blackfoot Field. Can Int J Sci Eng Res 7(8):1091-1101

9. Maurya SP, Singh KH (2019) Predicting porosity by multivariate regressions and probabilistic neural network using model-based and coloured inversion as external attribute: a quantitative comparison. J Geol Soc India 93:207-212. https://doi.org/10.1007/ s12594-019-1153-5

10. Maurya SP, Singh NP (2019) Estimating reservoir zone from seismic reflection data using maximum-likelihood sparse spike inversion technique: a case study from the Blackfoot field (Alberta, Canada). J Pet Explor Prod Technol 9:1907-1918. https ://doi.org/10.1007/s13202-018-0600-y

11. Mavko G, Nur A (1996) Rock physics, the link between rock properties and seismic interpretation abstracts. Norsk pertroleum forening, seminar geophysics for lithology prediction, Kristiansand, Norway, pp 187-192

12. Sherriff RE (2002) Encyclopedia dictionary of applied geophysics, 4th Edn. Society of Exploration Geophysicists

13. Karim SU, Islam MS, Hossain MM, Islam MA (2016) Seismic reservoir characterization using model based post-stack seismic inversion: in case of Fenchuganj gas field, Bangladesh. J Jpn Pet Inst 59(6):283-292

14. Filippova K, Kozhenkov A, Alabushin A (2011) Seismic inversion techniques: choice and benefits. First Break 29(5):103-114

15. Russell H (1999) Theory of the STRATA program. HampsonRussell, CGG Veritas
16. Chopra S, Michelena RJ (2011) Introduction to this special section: reservoir characterization. Lead Edge 30(1):35-37. https ://doi.org/10.1190/1.3535430

17. Somoza A, Kemper M, Waters K (2015) Extrapolating facies and rock physics trends across a basin for improved seismic inversion results - a demonstration from the Central North Sea, NCS Prospect Far

18. Oyedele KF, Ige-Adeyeye AA, Olatinsu OB (2017) Rock physics analysis and templates for an unconsolidated sand reservoir in aka field offshore Niger Delta. Pet Technol Dev J 7(1):5-21

19. Oyeyemi KD, Olowokere MT, Aizebeokhai AP (2019) Prospect analysis and hydrocarbon reservoir volume estimation in an exploration field, shallow offshore depobelt, western Niger Delta, Nigeria. Nat Resour Res 28:173-185. https://doi. org/10.1007/s11053-018-9377-4

20. Alabi A, Enikanselu PA (2019) Integrating seismic acoustic impedance inversion and attributes for reservoir analysis over "DJ" Field, Niger Delta. J Pet Explor Prod Technol 9(4):24872496. https://doi.org/10.1007/s13202-019-0720-z

21. Castagna JP, Batzle ML, Eastwood RL (1985) Relationships between compressional-wave and shear-wave velocities in clastic silicate rocks. Geophysics 40(2):571-581. https://doi. org/10.1190/1.1441933

22. Smith TM, Sayers CM, Sondergeld CH (2009) Rock properties in low porosity/low permeability sandstones. Lead Edge 28(1):4859. https://doi.org/10.1190/1.3064146

23. Guo Z, Li X (2015) Rock physics model-based prediction of shear wave velocity in the Barnett Shale formation. J Geophys Eng 12:527-534. https://doi.org/10.1088/1742-2132/12/3/527

24. Ganguli SS, Vedanti N, Dimri VP (2016) 4D reservoir characterization using well log data for feasible $\mathrm{CO} 2$-enhanced oil recovery at Ankleshwar, Cambay Basin-a rock physics diagnostic and modeling approach. J Appl Geophys 135:111-121. https://doi. org/10.1016/j.jappgeo.2016.10.007

25. Ganguli SS, Kumar P, Dimri VP (2019) Seismic anisotropy of a fractured rock during $\mathrm{CO} 2$ injection: a feasibility study. Acta Geophys 67(1):141-148

26. Sayers CM, den Boer LD (2011) Rock physics-based relations for density and S-velocity versus P-velocity in deepwater subsalt Gulf of Mexico shales. Lead Edge 30(12):1376-1381

27. Billman HG (1992) Offshore stratigraphy and paleontology of the Dahomey embayment. West Afr N.A.P.E. Bull 7(2):121-130

28. Short KC, Stauble AJ (1967) Outline of geology of Niger Delta. AAPG Bull 51(5):761-779

29. Evamy BD, Haremboure J, Kamerling P, Knaap WA, Molloy FA, Rowlands PH (1978) Hydrocarbon habitat of tertiary Niger Delta. AAPG Bull 62(1):1-39

30. Lawrence SR, Munday S, Bray R (2002) Regional geology and geophysics of the Eastern Gulf of Guinea (Niger Delta to Rio Muni). Lead Edge 21(11):1112-1117. https://doi. org/10.1190/1.1523752

31. Whiteman AJ (1982) Nigeria-Its petroleum geology. Resources and Potential, Graham and Trottam, London, p 394

32. Sonibare O, Alimi H, Jarvie D, Ehinola OA (2008) Origin and occurrence of crude oil in the Niger Delta, Nigeria. J Pet Sci Eng 61(2-4):99-107. https://doi.org/10.1016/j.petrol.2008.05.002

33. Etimita OO, Beka FT (2019) Heavy mineral analysis of eocene sands and sandstones of nanka formation. Cen Niger Delta Pet Prov Geol Ecol Landsc 24:1-6. https://doi.org/10.1080/24749 508.2019.163321

34. Doust H, Omatsola E (1990) Niger Delta. In: Edwards JD, Santogrossi PA (eds) Divergent/passive margin basins, vol 48. American Association of Petroleum Geologists, AAPG Memoir, Tulsa, pp 239-248 
35. Weber KJ, Daukoru EM (1975). Petroleum geology of the Niger delta. In: proceedings of the 9th world petroleum congress, Geology, vol 2. Applied Science Publishers, Ltd London, UK, pp 210-221

36. Etu-Efoetor JO (1997). Fundamental of petroleum geology: paragraphics, Port Harcourt

37. Selley RC (1997) The basins of Northwest Africa: structural evolution in sedimentary basins of the world. Elsevier 3:17-26. https ://doi.org/10.1016/S1874-5997(97)80005-6

38. Koledoye BA, Aydin A, May E (2003) A new process-based methodology for analysis of shale smear along normal faults in the Niger Delta. AAPG Bull 87(3):445-463

39. Reijers TJA, Petters SW, Nwajide CS (1997) The Niger Delta basin. In: Selley RC (ed) Africa Basins-Sedimentary basin of the World 3 Amsterdam, Elsevier Science, pp 151-172

40. Corredor F, Shaw JH, Bilotti F (2005) Structural styles in the deep-water fold and thrust belts of the Niger Delta. AAPG Bull 89(6):753-780

41. Mabon Limited (2020) Regional geology of the deepwater Niger Delta, prospectivity of the Nigeria-Sao Tome and Principe JDZ

42. Russell H (2007) STRATA. Hampson-Russell, CGG Veritas, BAPEX interpretation laboratory (Geophysical Division)

43. Russell B, Hampson D, Bankhead B (2006) An inversion primer. CSEG Rec 31(2):96-103

44. Lee K, Yoo DG, McMechan GA, Hwang N, Lee GH (2013) A twodimensional post-stack seismic inversion for acoustic impedance of gas and hydrate bearing deep-water sediments within the continental slope of the Ulleung Basin, East Sea Korea. Terr Atmos Ocean Sci 24:295-310
45. Ebere B (2016) Seismic lithofacies prediction and reservoir characterization in deep-offshore Niger Delta, Nigeria Ph.D. Dissertation, University of Lagos, Nigeria

46. Goodway W, Chen T, Downton J (1997) Improved AVO fluid detection and lithology discrimination using Lamé parameters; "'," and " fluid stack" from P and S Inversions: CSEG national convention expanded abstracts, pp 148-151

47. Close D, Taylor R, Nixon S (2015) Rock physics and quantitative interpretation using lambda-mu-rho in the Shipwreck Trough, Otway Basin: 24th international geophysical conference and exhibition. ASEG Ext Abstr. https://doi.org/10.1071/ASEG2015ab 074

48. Greenberg ML, Castagna JP (1992) Shear-wave velocity estimation in porous rocks: theoretical formulation, preliminary verification and applications. Geophys Prospect 40(2):195-209. https ://doi.org/10.1111/j.1365-2478.1992.tb00371.x

49. Horsfall OI, Omubo-Pepple VB, Tamunobereton-ari I (2014) Estimation of shear wave velocity for lithological variation in the Northwestern part of the Niger Delta Basin of Nigeria. Am J Sci Ind Res 5(1):13-22. https://doi.org/10.5251/ajsir.2014.5.1.13.22

50. Phipps GG, Carson TG (1982). The exploration applications of seismic DHI analysis in the Malay basin. offshore technology conference, 3-6 May, 1982, Houston, Texas

51. Onajite E (2014) Seismic data analysis techniques in hydrocarbon exploration. Elsevier, Amsterdam

Publisher's Note Springer Nature remains neutral with regard to jurisdictional claims in published maps and institutional affiliations. 